\title{
ミニシンポジウム記録 魚類における不妊化研究の最前線
}

\section{3. 遺伝子編集による大西洋サケの不妊化}

Lene Kleppe, ${ }^{1}$ Rolf B. Edvardsen, ${ }^{1}$

Kai Ove Skaftnesmo, ${ }^{1}$ Tomasz Furmanek, ${ }^{1}$

Per Gunnar Fjelldal, ${ }^{2}$ Tom Hansen, ${ }^{2}$

Rüdiger W. Schulz, ${ }^{3}$ Eva Andersson, ${ }^{1}$

Anne Hege Straume, ${ }^{1}$ Hilal Güralp, ${ }^{1}$ Anna Wargelius ${ }^{1}$

1ノルウェー海洋研究所,

2ノルウェー海洋研究所マトレステーション,

3オランダユトレヒト大学

3. Sterile Atlantic salmon by gene editing

LENE KLEPPE, ${ }^{1}$ ROLF B. EDVARDSEN, ${ }^{1}$ KAI OVE SKAFTNESMO, ${ }^{1}$ TOMASZ FURMANEK, ${ }^{1}$

PER GUNNAR FJELLDAL, ${ }^{2}$ TOM HANSEN, ${ }^{2}$

RÜDIGER W. SCHULZ, ${ }^{3}$ EvA ANDERSSON, ${ }^{1}$

ANNE HEGE STRAUME, ${ }^{1}$ HILAL GÜRALP ${ }^{1}$

AND ANNA WARGELIUS ${ }^{1}$

${ }^{1}$ Institute of Marine Research, Bergen, Norway. ${ }^{2}$ Institute

of Marine Research, Research station Matre, Matredal,

Norway. ${ }^{3}$ Utrecht University, Faculty of Science, Depart-

ment of Biology, Utrecht, The Netherlands

\section{Introduction}

Atlantic salmon is a major aquaculture species in Norway with more than 1.2 millon tons produced every year. However, further increase in production is currently hampered due to sustainability concerns including disease problems and genetic introgression from farmed escapees to wild salmon populations. The latter issue may be solved by using sterile salmon in the sea cages. One way to produce sterile salmon is through triploidization. However, triploid salmon are generally more sensitive to suboptimal rearing conditions, which may lead to several welfare problems. Therefore, alternative sterilization methods are being explored. The innovation of the highly efficient and potent CRISPR/Cas9 methodology allows gene editing of specific DNA sequences in any organism, thus for the first time permitting the editing of traits, including sterility, beneficial for sustainable aquaculture.

\section{Results}

Using CRISPR/Cas9 we have produced a sterile salmon by targeting a gene that is essential for primordi- al germ cell survival and further gametogenesis. ${ }^{1)}$ Furthermore, this germ cell-free (GCF) salmon does not enter puberty, ${ }^{2)}$ which is associated with reduced welfare and growth. ${ }^{3)}$ Preliminary data suggest that GCF salmon have a similar growth rate and welfare compared to wild type salmon. We are currently exploring a method to mass-produce GCF salmon, as well as additional target genes for possible sterility treatments.

\section{Discussion}

If we succeed in establishing a way to mass-produce $100 \%$ sterile salmon that will not enter puberty, this model will have significant commercial potential because it may solve the problem with genetic introgression from farmed escapees to wild populations of salmon, as well as issues with precocious maturation.

\section{References}

1) Wargelius A, Leininger S, Skaftnesmo KO, Kleppe L, Andersson E, Taranger GL, Schulz RW, Edvardsen RB. Dnd knockout ablates germ cells and demonstrates germ cell independent sex differentiation in Atlantic salmon. Sci. Rep. 2016; 6: 21284

2) Kleppe L, Andersson E, Skaftnesmo KO, Edvardsen RB, Fjelldal PG, Norberg B, Bogerd J, Schulz RW, Wargelius A. Sex steroid production associated with puberty is absent in germ cell-free salmon. Sci. Rep. 2017; 7 (1): 12584.

3) Taranger GL, Carrillo M, Schulz RW, Fontaine P, Zanuy S, Felip A, Weltzien FA, Dufour S, Karlsen O, Norberg B, Andersson E, Hansen T. Control of puberty in farmed fish. Gen. Comp. Endocrin. 2010; 165(3): 83-515.

\section{（和訳概要）}

ノルウェーでは大西洋サケを毎年 1.2 百万トン以上生 産している。しかし病気の問題や養殖場からの逃亡個体 による野生集団への遺伝的移入の問題などから, 現在更 なる増産は妨げられている。遺伝的移入の問題は，養殖 場のサケを不妊化することによって解決される。 CRISPR/Cas9 を使用して, 始原生殖細胞の生存々配偶 子形成に不可欠な遺伝子を遺伝子編集の標的とすること により，生殖細胞を持たない（GCF） サケの作出に成 功した。GCF サケは性成熟が起こらず，野生個体と同 様の成長率と繁殖力を持つというデータが得られてい る。現在，GCF サケを大量生産する方法の開発を進め て抢り，これに成功すれば，遺伝的移入の問題と早熟の 問題を解決できるため，大きな商業的可能性を持つこと になると考えられる。 (岡本裕之 訳) 